\title{
Peningkatan Kreatifitas Peserta Didik Melalui Metode Penugasan
}

\author{
MEINI YANTI \\ Tenaga Pengajar pada Dinas Pendidikan Kabupaten Kampar \\ SMP Negeri 4 Siak Hulu \\ Email: desniyuliet@yahoo.com
}

\begin{abstract}
The creativity of learners in the learning process is mainly related to the management of education and training is needed and become the standard of competence that should be obtained. But at educational institutions most of the efforts to improve creativity is still not successful. During this effort to foster creativity of learners is based on efforts to motivate and consequently less than optimal. Through the method of assignment with the application of classroom action research and qualitative data analysis obtained the result that through the method of assignment to learners with the limits of assessment results then the creativity of learners in learning is increasing.
\end{abstract}

Keywords: Creativity, Assignment

Drama satu babak adalah suatu bentuk karya sastra berupa naskah dan lakon yang terdiri atas satu babak, berpusat pada satu tema dengen sejumlah kecil. Pameran gaya, latar, serta penaluran yang ringkas (Sumber:Kamus Besar Bahasa Indonesia. Edisi:3) Drama satu babak memunyai karakter yang lebih sedikit dan mungkin latar yang lebih sederhana. Biasanya, drama satu babak hanya berfokus pada karakter utama dan satu kejadian atau satu tujuan. Sementara waktu untuk subalur (subplot) dan adegan yang tidak melibatkan karakter utama, kisahnya hanya sedikit. Inilah yang harus Anda perhatikan saat membaca drama satu babak, dan sesuatu yang perlu diingat saat Anda masuk ke dalam proses menulis

Menulis menulis kreatif naskah drama satu babak ilmiah sangat penting untuk dikuasai. Sebuah menulis kreatif naskah drama satu babak ilmiah sangat bermanfaat jika hal yang dibahasnya sangat berhubungan dengan kehidupan sehari-hari. Akan tetapi, sebelum menulisnya, kita harus melakukan penelitian. Penelitian dalam bentuk kepustakaan atau secara langsung melakukan percobaan.

Belajar Bahasa Indonesia khususnya pada aspek menulis kreatif naskah drama satu babak dibutuhkan siswa yang benarbenar bisa melahirkan dan menampilkan jati dirinya, rasa percaya diri yang tinggi dan bahkan siswa mampu mengeksploitasi dirinya dalam menghasilkan hasil karya berupa naskah drama satu babak. Bagi sebagian siswa membuat menulis kreatif naskah drama satu babak adalah hal yang biasa, namun sebagian siswa lainnya membuat menulis kreatif naskah drama satu babak menjadi hal yang menakutkan.

Siswa pada saat belajar membuat menulis kreatif naskah drama satu babak mengalami ketakutan ditugaskan untuk membuat menulis kreatif naskah drama satu babak selain itu juga, yang lebih parah adalah ketakutan pada saat ingin menyajikan hasil karyanya dalam bentuk persentasi langsung di ruang kelas. Hal tersebut menjadi masalah tersendiri bagi keberhasilan guru dalam hal ini adalah guru yang memberikan pengajaran mata pelajaran bahasa Indonesia.

Di dalam pelajaran bahasa indonesia selain mendengarkan, memahami siswa juga dituntut untuk mampu menghasilkan karya yang lebih dapat dinikmati orang lain. Permasalahan yang terjadi di SMP N 4 Siak Hulu, yakni rendahnya kreatifitas siswa dalam menulis kreatif naskah drama satu babak dalam hal ini adalah menulis naskah drama satu babak, siswa lebih hanya mampu membaca tanpa ada usaha untuk mencermati dan bahkan untuk membuat naskah drama satu babak. 
Berdasarkan beberapa pendapat para ahli berkaitan dengan masalah sebagaimana disampaikan oleh Siswono, T. Y. E. (2005) bahwa tidak semua aspek kemampuan berpikir kreatif meningkat terutama fleksibilitas dalam memecahkan masalah. Tetapi untuk aspek pemahaman terhadap informasi masalah, kebaruan dan kefasihan dalam menjawab soal mengalami peningkatan. Hasil lain menunjukkan bahwa kemampuan memecahkan masalah dan mengajukan masalah mengalami kemajuan/peningkatan.

Hasil tersebut menunjukkan bahwa untuk meningkatkan kreatifitas mengunakan menggunakan metode pengajuan masalah, selain itu juga pendapat lain yang berbicara masalah meningkatkan kreatifitas belajar yakni menurut pendapat Marlinda, N. L. P. M. (2012) terdapat perbedaan kemampuan berpikir kreatif dan kinerja ilmiah antara kelompok siswa yang belajar dengan MPjBL dan kelompok siswa yang belajar. selanjutnya Wibowo, F. C., \& Suhandi, A. (2013) menjelaskan bahwa setelah penerapan model pembelajaran sebagian besar hasil belajar dan keterampilan berpikir kreatif meningkat kategori sedang. Hal ini diindikasikan oleh rata-rata skor gain yang dinormalisasi $\langle\mathrm{g}\rangle$ hasil belajar kognitif dan $<\mathrm{g}>$ keterampilan berpikir kreatif meningkat sebesar 0,44. Hasil-hasil ini menunjukkan bahwa model SCL fisika berbasis proyek merupakan salah satu model pembelajaran yang dapat meningkatkan hasil belajar kognitif dan keterampilan berpikir kreatif.

Widyaninggar, R. (2009) menjelaskan

1) adanya peningkatan kreatifitas dan pemahaman konsep keliling dan luas segitiga yang dapat dilihat dari a) keaktifan bertanya sebelum dilakukan tindakan sebesar $0 \%$ dan setelah dilakukan tindakan sebesar $47,5 \%$, b) keaktifan mengemukakan ide sebelum dilakukan tindakan sebesar $0 \%$ dan setelah dilakukan tindakan sebesar $30 \%$, c) keaktifan mengerjakan soal latihan sebelum dilakukan tindakan sebesar $10 \%$ dan setelah dilakukan tindakan sebesar $67,5 \%$, serta 2) adanya peningkatan prestasi belajar siswa terlihat dari hasil belajar siswa yang mendapatkan nilai $\geq 60$ meningkat dari 57,125\% menjadi $74,623 \%$. Penelitian ini menyimpulkan bahwa penggunaan metode pembelajaran think-pair-share dapat meningkatkan kreatifitas belajar dan pemahaman konsep keliling dan luas segitiga sehingga berdampak pada peningkatan belajar siswa.

Firmanto, A. (2013) menjelaskan variabel kecerdasan, kreativitas dan task commitment merupakan variabel yang memiliki kontribusi kuat terhadap prestasi hasil belajar. Pada siswa laki-laki, kecerdasan dapat dijadikan aspek utama sebagai prediktor, sedangkan pada siswa perempuan prediktor utama adalah kecerdasan dan task commitment. Selanjutnya, perlu dipertimbangkan faktor eksternal yang turut berpengaruh pada capaian hasil belajar. Proses yang terjadi diluar siswa perlu dicermati bahkan diarahkan menjadi faktor pendukung, antara lain adalah interaksi edukasi yang merupakan inti dari proses belajar mengajar. Upaya tersebut dapat diwujudkan sebagai pendidikan karakter yang bertujuan menjadikan siswa sebagai insan yang cerdas, kreatif, mandiri, bertanggungjawab dan berbudi pekerti.

Apabila dicermati sebagain besar usaha kreatif dengan menggunakan metode pengajuan persoalan dan pemecahan persoalan. Apakah untuk untuk kajian sosial bisa diterapkan metode penugasan. Seorang guru dalam mengajar memberikan tugas kepada peserta didik.

Slameto (1991: 84) menyebutkan bahwa: "mengajar adalah kegiatan mengorganisasi yang bertujuan untuk membantu dan menggairahkan siswa belajar". Mengajar dapat diartikan sebagai proses menyampaikan pengetahuan dan kecakapan tertentu kepada anak didik. Yang lain menyebutkan bahwa mengajar adalah mengorganisasi lingkungan secara kondusif sehingga dapat menciptakan siswa untuk melakukan proses belajar secara efektif.

Soetomo (1993: 160) menyebutkan bahwa metode penugasan adalah penugasan dari guru kepada anak-anak untuk diselesaikan dan dipertanggungjawabkan. Tugas dapat 
diberikan di rumah, maupun disekolah pada saat kegiatan belajar mengajar berlangsung.

Drama satu babak memunyai karakter yang lebih sedikit dan mungkin latar yang lebih sederhana. Biasanya, drama satu babak hanya berfokus pada karakter utama dan satu kejadian atau satu tujuan. Sementara waktu untuk subalur (subplot) dan adegan yang tidak melibatkan karakter utama, kisahnya hanya sedikit. Inilah yang harus Anda perhatikan saat membaca drama satu babak, dan sesuatu yang perlu diingat saat Anda masuk ke dalam proses menulis.

\section{METODE}

Metode yang digunakan dalam penelitian ini adalah metode penelitian tindakan kelas (PTK). PTK bertujuan untuk mencari pemecahan permasalahan nyata yang terjadi di kelas, sekaligus mencari jawaban ilmiah bagaimana masalah-masalah tersebut bisa dipecahkan melalui suatu tindakan perbaikan. Kegiatan penelitian tindakan kelas ini terdiri atas beberapa tahap yaitu: Perencanaan; Pelaksanaan; Pengamatan; dan Refleksi.

Yang menjadi subjek penelitian tindakan kelas ini adalah guru bersama dengan siswa di kelas VIII SMP N 4 Siak Hulu Kabupaten Kampar yang berjumlah 39 orang. Teknik pengumpulan data dari penelitian tindakan sekolah ini adalah melalui data kualitatif yang diperoleh dari observasi, pengamatan, maupun wawancara.

Analisa data yang digunakan dalam penelitian ini adalah analisa data kualitatif yang bersumber dari data primer maupun empiris. Melalui analisa data ini, dapat diketahui ada tidaknya peningkatan kreatifiitas siswa membuat naskah drama satu babak pada mata pelajaran bahasa indonesia melalui penerapan metode penugasan yang merupakan fokus dari penelitian tindakan kelas ini.

\section{HASIL}

Penelitian tindakan kelas (PTK) ini dilaksanakan dalam tiga siklus. Hal ini dikarenakan keterbatasan waktu yang tersedia, serta dengan tiga siklus sudah penulis anggap cukup untuk peningkatan kreatifiitas siswa memahami naskah drama satu babak di kelas.

Siklus 1 terdiri beberapa tahapan, yaitu: 1) Perencanaan; 2) Pelaksanaan; 3) Pengamatan dan 4) Refleksi.

1. Perencanaan. Perencanaan adalah langkah awal yang dilakukan oleh penulis saat akan memulai tindakan. Agar perencanaan mudah dipahami dan dilaksanakan oleh penulis yang akan melakukan tindakan, maka penulis akan membuat rencana tindakan sebagai berikut: Merumuskan masalah yang akan dicari solusinya; Merumuskan tujuan penyelesaian masalah/tujuan menghadapi tantangan/tujuan melakukan inovasi/tindakan; Merumuskan indikator keberhasilan penerapan metode penugasan

2. Pelaksanaan. Pelaksanaan penelitian tindakan kelas ini dilaksanakan melalui beberapa kegiatan, antara lain: Menyebarkan lembar pengamatan kepada setiap siswa sebanyak 39 set sesuai dengan banyaknya siswa pada kelas VIII di SMP N 4 Siak Hulu 39 orang. Dalam lembar pengamatan itu, telah dibuat pertanyaan mengenai kreatif atau tidaknya dalam membuat naskah drama satu babak dengan memberikan tanda contreng pada pilihan jawaban yang dianggap paling sesuai; Berkoordinasi dengan guru mata pelajaran bahasa indoensia, guru akan mengajak siswa dalam membuat naskah drama satu babak dengan tugas bebas; Setelah selesai mengumpulkan data, dilakukan rekapitulasi data penelitian; Kegiatan tersebut dilakukan terus kepada setiap siswa pada tahapannya.

3. Pengamatan. Pengamatan atau observasi dilakukan oleh peneliti, dengan menggunakan lembar observasi selama 1 bulan (satu siklus), untuk semua siswa kelas VIII yang berjumlah 39 orang.

Rekapitulasi tingkat pemahaman 
siswa dalam membuat naskah drama satu babak melalui metode penugasan di kelas VIII mata pelajaran bahasa indonesia dilihat dari naskah drama satu babak yang dibuat dan menyampaikan pertanyaan dapat dilihat pada table rekap berikut:

\section{Gambar 1 Grafik Peningkatan Kreatifitas Peserta Didik}

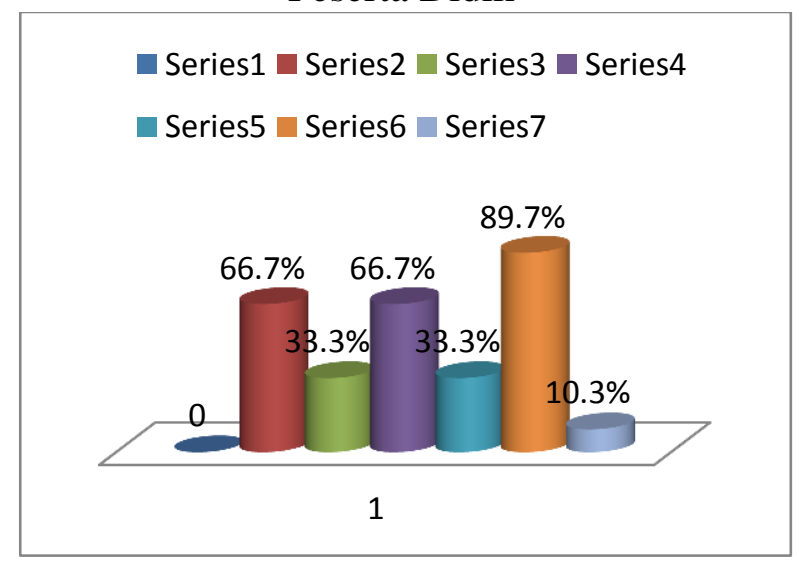

\section{PEMBAHASAN}

Setelah selesai pelaksanaan tindakan pada siklus ketiga maka diadakan refleksi mengenai kelemahan atau kekurangan dari pelaksanaan tindakan pada siklus kedua tersebut. Dari hasil observasi dan data yang diperoleh, peneliti mengambil kesimpulan bahwa tindakan yang dilaksanakan pada siklus ketiga dinyatakan lebih baik bila dibandingkan dengan siklus pertama dan kedua.

Terbukti bahwa penerapan metode penugasan dalam rangka meningkatkan pemahaman terhadap naskah drama satu babak di kelas VIII pada mata pelajaran bahasa indonesia ternyata mampu meningkatkan pemahaman siswa.

\section{SIMPULAN}

Melalui metode penugasan dengan penerapan penelitian tindakan kelas dan analisis data kualitatif diperoleh hasil bahwa melalui metode penugasan kepada peserta didik dengan batas pemberian penilaian hasil maka kreatifitas peserta didik dalam belajar semakin meningkat.

\section{DAFTAR RUJUKAN}

Siswono, T. Y. E. (2005). Upaya meningkatkan kemampuan berpikir kreatif siswa melalui pengajuan masalah. Jurnal Pendidikan Matematika dan Sains, 10(1), 1-9.

Marlinda, N. L. P. M. (2012). Pengaruh model pembelajaran berbasis proyek terhadap kemampuan berpikir kreatif dan kinerja ilmiah siswa. Jurnal Pendidikan IPA, 2(2).

Wibowo, F. C., \& Suhandi, A. (2013). Penerapan Model Science Creative Learning (SCL) Fisika Berbasis Proyek Untuk Meningkatkan Hasil Belajar Kognitif dan Keterampilan Berpikir Kreatif. Jurnal Pendidikan IPA Indonesia, 2(1).

Widyaninggar, R. (2009). Peningkatan Kreatifitas Belajar Dan Pemahaman Konsep Matematika Dengan Penerapan Pembelajaran Kooperatif Think-Pair-Share (Tps)(PTK Pembelajaran Matematika Kelas VII SMP N 3 Bae Kudus) (Doctoral dissertation, Universitas Muhammadiyah Surakarta).

Firmanto, A. (2013). Kecerdasan, kreatifitas, task commitment dan jenis kelamin sebagai prediktor prestasi hasil belajar siswa. Jurnal Sains dan Praktik Psikologi, 1(1).

Slameto, 2003, Belajar dan factor-faktor yang mempengaruhinya, Jakarta: Rineka Cipta.

Soetomo, 1993, Dasar-dasar interaksi belajar mengajar, Usaha nasional, Surabaya 